\title{
KOMBINASI KECERDASAN INTELEKTUAL DAN KECERDASAN SPIRITUAL DALAM PENDIDIKAN ERA GLOBAL
}

\section{Bi'ah*}

Institut Agama Islam Negeri (IAIN) Antasari Jalan Ahmad Yani km. 4.5 Banjarmasin e-mail:biah@iain-antasari.ac.id

\begin{abstract}
The era development is something absolute. Each country must work together to improve the quality of their nation because the globalization is something that cannot denied. Along with globalization, the problem arose especially in education. Education that focuses only on the intellectual level of the output makes the output of education is getting away from traditional values, culture and nation religious value should be preserved. To counteract the negative effects of the globalization, it is required education that is not only pursuit intellectual of success but also combine them with spiritual intelligence. It is expected for the quality of graduates intellectually and spiritually.
\end{abstract}

\begin{abstract}
Abstrak
Kemajuan zaman serta perubahan merupakan sesuatu yang mutlak. Setiap negara harus saling bekerjasama untuk meningkatkan taraf kualitas bangsa mereka sehingga arus globalisasi menjadi sesuatu yang tidak terlelakkan. Seiring dengan globalisasi muncullah masalah yang mengiringinya terutama dalam dunia pendidikan. Pendidikan yang hanya memfokuskan pada tingkat intelektual outputnya menjadikan output pendidikan semakin menjauh dari nilai-nilai adat, budaya dan religiulitas bangsa yang harusnya terjaga. Untuk menangkal efek negatif dari arus globalisasi yang besar diperlukan pendidikan yang tidak hanya mengejar kesuksesan intelektual tetapi juga mengombinasikannya dengan kecerdasan spiritual. Dari sinilah diharapkan lulusan yang berkualitas secara intelektual dan spiritual.
\end{abstract}

Kata Kunci : Globalisasi, kecerdasan intelektual, kecerdasan spiritual

* Penulis adalah mahasiswi semester 3 Program Pascasarjana IAIN Antasari Program Studi Manajemen Pendidikan Islam TA. 2013/2014 


\section{A. PENDAHULUAN}

Kemajuan zaman serta perubahan merupakan suatu yang tidak terelakkan bagi semua negara diseluruh dunia. Hal ini mengharuskan tiap negara siap dengan arus globalisasi yang tidak terbendung. Globalisasi tidak mengenal waktu dan tempat dimana masyarakat di seluruh dunia menjadi saling tergantung pada semua aspek kehidupan baik secara budaya, ekonomi, maupun politik.

Di era globalisasi suatu negara memiliki keitimewaan tersendiri dalam hal iptek, budaya, hukum, ekonomi, politik, pendidikan, sehingga suatu negara perlu menjalin kerjasama dengan negara lain dalam korporasi ${ }^{1}$ yang saling menguntungkan. Hal ini mengharuskan negara-negara di dunia bergabung dalam organisasi internasional seperti: PBB, ASEAN, G20, dan OKI. Hubungan ini tidak hanya akan berimbas pada bidang iptek, hukum, ekonomi, politik, pendidikan tetapi juga memungkinkan terjadinya pertukaran budaya dan adat dalam kehidupan masyarakat. Perubahan masyarakat yang terpenting pada era global, ditandai dengan perkembangan teknologi komunikasi, transportasi, dan informasi yang sedemikian cepat. Sesuatu yang terjadi di belahan bumi paling ujung dapat segera diketahui oleh masyarakat yang berada di ujung lain.

Kemajuan intelektual juga menjadi aspek positif dari globalisasi misalnya saja kemampuan Indonesia mampu maju dalam kancah pertandingan internasional misalnya sampai saat ini Indonesia sudah mengumpulkan sekitar 100 medali emas di bidang sains (aidnu, 2013).

Dalam konteks ekonomi politik, kenyataan globalisasi dijadikan faktor penting untuk melihat kemungkinan memudarnya batas-batas teritorial negara-bangsa, yang oleh Kenichi Ohmae disebut the end of the nation state. ${ }^{2}$ Dari sisi politik, dapat dikatakan bahwa masyarakat global sangat dekat dengan isu-isu populer, seperti keterbukaan, hak asasi manusia, dan demokratisasi. Demikian pula, dari sudut ekonomi, perdagangan, dan pasar internasional. Sebagaimana dikatakan oleh Ahmed dan Davis They locked together in what has been referred to as the economic world system. ${ }^{3}$ Dalam kerangka struktur berpikir masyarakat agama, proses globalisasi dianggap berpengaruh atas kelangsungan perkembangan identitas tradisional dan nilai-nilai agama (Endang Komara, 2005).

Arus globalisasi juga telah menimbulkan dampak negatif tersendiri dalam pola kehidupan masyarakat khususnya di Indonesia. Indonesia saat ini mengalami krisis " multi dimensi" yang artinya krisis yang melanda semua kehidupan bangsa tidak hanya bidang finansial moneter. (Nurcholish Madjid, 2004: 113). Masuknya nilai, budaya bebas dan

\footnotetext{
${ }^{1}$ Pada awalnya korporasi atau badan hukum adalah subjek yamg hanya dikenal dalam hukum perdata, apa yang sebenarnya dinamakan badan hukum itu adalah ciptaan hukum, yaitu menunjuk kepada adanya suatu badan yang diberi status sebagai subjek hukum, selain subjek hukum yang berwujud manusia alamiah . Lihat Kitab UU hukum perdata pasal 1654 namun kemudian korporasi berkembang menjadi kerjsama dibidang ekonomi. Lihat juga Pasal 1 angka 15 Undang-Undang No. 31 tahun 2004 tentang perikanan.

${ }^{2}$ Maksud dari the end of nation state adalah setiap negara itu tidak lagi terlihat sebagai suatu negara yang terpisah pisah, sehingga dikatakan bahwa hal ini adalah akhir dari negara kebangsaan.

${ }^{3}$ Mereka bekerjasama dan menunjuknya sebagai sistem ekonomi dunia
} 
hedonis dari luar telah menggeser norma-norma adat, budaya, sosial serta agama masyarakat. Seperti pergaulan bebas di kalangan remaja, penggunaan narkoba, korupsi, dan kejahatan sosial ditengah masyarakat.

Dunia pendidikan sendiri sering tercoreng oleh dampak negatif globalisasi yang tidak terbendung disebabkan perilaku melanggar hukum oleh para remaja yang notabene adalah pelajar. Misalnya saja berdasarkan data survei Seks Bebas di Kalangan Remaja oleh $\mathrm{BKKBN}^{4}$, putri di kota-kota besar cenderung sudah tidak perawan. Hasil survei menunjukkan bahwa separuh dari perempuan lajang di kota besar khususnya Jabotabek kehilangan keperawanan dan melakukan hubungan seks pranikah (Okezone.com, 2013).

Pengguna narkotika, psikotropika, dan zat adiktif (napza) diperkirakan sekitar 5 juta orang atau 2,8 persen dari total penduduk Indonesia. Angka ini lebih tinggi daripada jumlah penduduk Nusa Tenggara Timur yang mencapai 4,6 juta jiwa. Pengguna remaja yang berusia 12-21 tahun ditaksir sekitar 14.000 orang dari jumlah remaja di Indonesia sekitar 70 juta orang. (Kompas, 2013).

Menurut data $\mathrm{KPAI}^{5}$ (Kompas, 2012) kasus tawuran pelajar di wilayah Jabodetabek mengalami peningkatan dalam tiga tahun terakhir, dari 2010 hingga 2012. Pada 2010, ada 102 kasus tawuran pelajar, lantas menurun pada 2011 (96 kasus), dan meningkat lagi pada 2012 (103 kasus). Jenjang pelaku tawuran pelajar cukup variatif, dari SD hingga SMA/K. Tercatat, jumlah pelaku dari jenjang SD lebih sedikit (2-4 orang) dibandingkan dengan jumlah pelaku dari jenjang SMA/K (28-43 orang).

Dampak negatif seiring dengan masuknya era globalisasi disegala bidang merupakan hal yang tidak terelakkan. Pendidikan sebagai sarana terpenting dalam mencetak generasi unggul masa depan merupakan jembatan utama untuk menghadapi dampak negatif dari arus globalisasi yang tidak bisa kita tolak. Pendidikan berperan penting dalam mencetak generasi yang unggul dalam bidang intelektual tanpa meninggalkan nilai spiritual. Output pendidikan yang baik tentu menjadi indikator keberhasilan pendidikan sebagai jembatan pembentuk karakter bangsa sebab jika pendidikan saja sering tercoreng dengan hal-hal negatif maka kita akan memiliki persepsi bahwa proses pendidikan itupun telah gagal untuk membentuk generasi bangsa yang berkarakter di masa depan.

Disisi lain hal ini akan berdampak positif dalam menjaga adat dan budaya kita sebagai orang timur. Sehingga ketika gencarnya arus globalisasi yang masuk tidak akan menggoda generasi unggul kita untuk mengambil dampak negatifnya. Sebagaimana diungkapkan Azizy (2004: 25), apabila globalisasi itu memang memberi hal-hal, nilai, dan praktek yang positif yang tidak berbenturan dengan budaya lokal, nasional, dan terutama sekali nilai agama, haruslah menjadi tantangan bagi bangsa Indonesia untuk mampu menyerapnya.

\footnotetext{
${ }^{4}$ Badan Kependudukan dan Keluarga Berencana Nasional merupakan suatu lembaga pemerintah Non Departemen Indonesia yang melaksanakan tugas pemerintah di bidang keluarga berencana dan keluarga sejahtera sesuai dengan ketentuan perundang-undangan yang berlaku. Tugasnya diantaranya meliputi pengkajian dan penyusunan kebijakan nasional, fasilitasi dan pembinaan di bidang keluarga berencana dan keluarga sejahtera,

${ }^{5}$ Komisi Perlindungan Anak Indonesia
} 
Tentunya hal ini mengharuskan kita menyiapkan dengan seksama bagaimana agar nilai positif dari globalisasi dapat kita ambil sedangkan nilai negatifnya dapat kita minimalisir bahkan kita buang.

Salah satu permasalahan kronis yang dihadapi oleh generasi bangsa Indonesia sekarang ini dikarenakan adanya arus globalisasi yang tidak terbendung adalah rusaknya kepribadian akibat tidak terhubungnya otak dengan hati. Untuk ini dunia pendidikan di era global haruslah memiliki nilai keutamaan spiritual untuk mengiringi kecerdasan intelektual yang ingin dicapai. Kecerdasan spiritual adalah sebuah kunci kercerdasan yang tidak hanya menekankan hubungan manusia dengan Tuhan tapi jauh lebih dari itu, kecerdasan spiritual akan menghadirkan ruh tersendiri dalam perbuatan manusia. Perbuatan manusia yang dihasilkan oleh kecerdasan intelektualnya akan mampu meraih nilai positif dengan ruh yang dihadirkan oleh kecerdasan spiritual. Dalam prosesya tentu keduanya tidak bisa dipisahkan, artinya satu sama lain harus dijalankan bersamaan.

\section{B. PERSFEKTIF PENDIDIKAN ERA GLOBAL}

Globalisasi secara umum, sebagaimana diungkapkan Sztompka (2004: 101-102), dapat diartikan sebagai proses yang menghasilkan dunia tunggal. Artinya, masyarakat di seluruh dunia menjadi saling tergantung pada semua aspek kehidupan baik secara budaya, ekonomi, maupun politik, sehingga cakupan saling ketergantungan benar-benar mengglobal. Sedangkan Menurut Giddens (Nanang Fatah, 2012: 139) globalisasi merupakan transformasi waktu dan ruang. Lebih jelasnya Giddens mendefinisikan globalisasi sebagai "kegiatan dari jauh" (action at a distance). Action of distance merujuk pada saling keterhubungan (interconnectedness) dari kegiatan ekonomi, politik, dan budaya diseluruh dunia. Produknya tidak hanya sistem dengan skala yang besar, tetapi juga transformasi lokal dan bahkan dalam konteks perseorangan/ personal dari pengalaman sosial.

Melihat konteks pengertian globalisasi diatas, adalah hal yang mustahil bagi kita untuk menghindari kontak dengan negara-negara lain diseluruh dunia. Prinsip manusia sebagai makhluk sosial secara harfiah telah mengharuskan manusia hidup saling bergantung dan tidak bisa berdiri sendiri tanpa hubungan dengan orang lain. Dalam konteks kebijakan disuatu negara tentu ini kita lihat sebagai sesuatu yang harus terkoneksi dengan ketetapan internasional terhadap suatu produk yang kita hasilkan dalam negara kita. Karena adanya hubungan dengan negara-negara lain menyebabkan suatu negara harus mampu memenuhi standar baku yang diakui oleh semua negara sebagai satu kesatuan pandangan dalam berbagai kebijakan. Tanpa mengikuti standar ini akan sulit bagi kita untuk diakui di dunia internasional. Hanya saja ketika kita meletakkan standar internasional dalam pengambilan keputusan atau kebijakan dalam negara kita, tidaklah boleh meninggalkan nilai-nilai yang pada dasarnya sudah melekat dalam jati diri bangsa kita seperti nilai adat, budaya, serta norma-norma agama yang berlaku. Berstandar internasional bukan berarti melepaskan jati diri kita justru sebaliknya standar ini harus mampu menjadi standar yang menunjukkan eksistensi jati diri bangsa kita sebagaimana yang amanatkan oleh Undang-Undang Dasar 1945. 
Pendidikan di era globalisasi sendiri haruslah dikembalikan pada makna dari pendidikan itu sendiri. Menurut Darmaningtyas (1999: 3) pendidikan haruslah dimengerti secara luas dan umum sebagai usaha sadar yang dilakukan oleh pendidik melalui bimbingan, pengajaran, dan latihan untuk membantu peserta didik mengalami proses kemanusiaan ke arah tercapainya pribadi yang dewasa susila. yakni sosok manusia dewasa yang sudah terisi secara penuh bekal ilmu pengetahuan serta memiliki integritas moral yang tinggi. Sehingga dalam perjalanannya nanti manusia seperti ini adalah manusia-manusia yang selalu siap, baik jasmani maupun rohani. Dalam hal ini terlihat jelas bahwa jika pendidikan itu dikembalikan pada maknanya maka proses pendidikan sendiri bukan hanya penyajian seperangkat mata pelajaran dalam dunia sekolah. Akan tetapi pendidikan dapat dilihat lebih mendalam sebagai upaya untuk memanusiakan manusia sehingga ia bukan hanya menjadi manusia yang cerdas secara intelektual tetapi juga memiliki nilai spiritualitas yang tinggi dimana hal ini berefek langsung pada pembentukan karakter pribadinya yang memiliki integrasi moral yang tinggi.

Sebagaimana disebutkan UU Sisdiknas No. 20 tahun 2003 yang bertujuan menyiapkan sumber daya manusia (SDM) yang mampu berperan sebagai subjek pembangunan nasional. Lebih dari itu pendidikan diharapkan dapat melahirkan SDM yang berkualitas, memiliki kompetensi, berkarakter, dan berdaya saing tinggi, baik pada tingkat regional (ASEAN), maupun internasional di era globalisasi. Tujuan ini secara tidak langsung menyiratkan bahwa output pendidikan yang diharapkan tidak hanya sekedar memiliki kemampuan dan terampil dibidangnya serta mampu bersaing di dunia internasional tetapi juga tetap mengemban jati diri bangsa sebagaimana harapan SDM yang berkarakter yang diharapkan terbentuk dalam tujuan Undang-Undang yang disebutkan. Tentu saja dua hal diatas menunjukkan bahwa pendidikan era global yang dicanangkan bukanlah pendidikan yang hanya melandaskan pada keberhasilan secara intelektual tapi juga seimbang secara spiritual dimana kita pahami bahwa kecerdasan spiritual ini merupakan karakter yang kuat melekat dalam diri bangsa Indonesia sebagaimana tercakup dalam Pancasila sila pertama "Ketuhanan Yang Maha Esa". Identitas inilah yang diharapkan dibawa oleh output pendidikan Bangsa Indonesia kedepannya agar mampu bersaing secara global tanpa meninggalkan nilai-nilai spiritual yang menjadi karakter yang dimiliki bangsa ini.

Pendidikan merupakan salah satu unsur untuk mengembangkan pembangunan. Kecerdasan pendidikan yang hanya mencukupkan pada ketercapaian intelektual saja tentu akan menghasilkan ketimpangan sosial dalam pelaksanaannya dikarenakan pembangunan ini hanya akan menghasilkan orang-orang yang ambisius dalam mencapai target pembangunan yang semu, karena ia menjadi sesuatu yang kosong dari sisi pencapaian pendidikan dan jauh dari karakter bangsa. Sebagaimana dikatakan oleh Malik Fajar (1999: 18) adanya agenda pembangunan nasional tidak lagi menjadi kendala untuk direalisasikan. Karena suatu pembangunan dapat berjalan, apabila di dukung oleh manusia pembangunan. Sebaliknya akan mendapat hambatan apabila manusianya tidak mampu melakukan pembangunan karena adanya hambatan pendidikan. Jika kita kembalikan pada tujuan pendidikan nasional di atas maka hambatan pendidikan itu tidak hanya terkait dengan proses serta sarana dan prasarana yang mengirinya tetapi juga pada bagaimana output 
yang dihasilkan kemudian oleh pendidikan. Sebab output yang memiliki kualitas tinggi baik secara intelektual maupun spiritual akan mampu menopang pembangunan yang dituju semakin cepat. Sebaliknya jika output yang dhasilkan hanya baik dari satu sisi saja maka ini dapat memperlambat pembangunan.

Suatu negara menyelenggarakan pendidikan bagi bangsanya dengan maksud mencerdaskan rakyat, meningkatkan pengetahuan, mereka demi kesejahteraan bersama yang pada gilirannya akan menjadikan negara itu mengalami kemajuan. Akan tetapi, pendidikan disuatu negara perlu melihat kemajuan pendidikan yang dicapai oleh negara lain. Itulah sebabnya, dalam melaksanakan suatu pendidikan suatu negara perlu melakukan perbandingan terhadap pelaksanaan pendidikan dinegara lain, mengetahui persamaan dan perbedaannya, kelebihan dan kelemahannya, lalu mengambil unsur positifnya sekaligus menyesuaikan dengan kondisi lokal. Tentu saja pengalaman pendidikan disuatu negara tidak bisa langsung diaplikasikan ke negara lain karena adanya perbedaan budaya, politik, hukum, ekonomi, dan lainnya. Namun pada taraf tertentu, prinsip umum yang menjiwai suatu penyelenggaraan pendidikan dapat berlaku secara global dinegara lain. Adapun pratiknya bisa disesuaikan dengan negara yang bersangkutan. Bisa dikatakan bahwa pendidikan era global baik yang dianut di Indonesia maupun dunia pada dasarnya merupakan pendidikan yang berstandar nasional tanpa meninggalkan jati diri bangsa masing-masing. Suatu kebijakan pendidikan yang dijalankan di suatu negara harus benarbenar memperhatikan aspek adat, budaya serta norma yang berlaku dalam negara masingmasing.

Dibalik adanya perbandingan pendidikan antar negara ada masalah yang harus dihadapi, diantaranya:

Pertama, studi lintas negara bila tidak diawali dengan keyakinan identitas bangsa, proteksi terhadap budaya sendiri, dan jati diri negara dapat saja berdampak pada erosi budaya, terutama bila kesan segala sesuatu yang berasal dari Barat adalah identik dengan kemajuan, modern, atau canggih masih ada. Persepsi ini menghambat kemajuan negara sesuai dengan identitasnya sendiri. Membandingkan pendidikan dinegara lain tidaklah perlu meleburkan diri dengan kondisi dinegara lain. Contohnya Jepang yang menjadi negara maju setelah menganut politik membuka diri dengan budaya luar tanpa harus meninggalkan budaya nasionalnya. Baju kimono masih dipakai, upacara adat serta seni dan tradisi lokal tetap bertahan ditengah kemajuannya. Sehingga penting bagi bangsa Indonesia untuk belajar menerima dan menyesuaikan pendidikan yang diadopsi dari unsurunsur luar tanpa meninggalkan identitas bangsa. Hal ini akan berfungsi sebagai proteksi bagi negara kita dalam menjaga keberadaan diantara negara lain dalam dunia pendidikan internasional

Kedua, seringkali upaya perbandingan pendidikan antarnegara ini berhenti pada tataran konsep pendidikan suatu negara semata, tidak diteruskan dengan kebijakan follow up yang jelas, baik karena alasan teknis, dana, SDM, keterkaitan dengan budaya nasional, maupun lainnya. Pembaharuan pendidikan nasional pun berjalan secara alami. Percepatan pembenahan pendidikan nasional umumnya dilakukan diluar upaya perbandingan 
pendidikan antarnegara, misalnya akibat tuntutan masyarakat, perubahan konstelasi politik nasional, atau lainnya. Sehingga penyusunan kurikulum dalam pendidikan harus melakukan penilaian kebutuhan secara seksama dimana baik siswa maupun masyarakat dijadikan aspek penting dalam pengambilan keputusan kebijakan pendidikan sebuah negara. Melihat dari kebutuhan individu, masyarakat, propinsi, nasional serta internasional agar semuanya bisa disinergiskan sehingga pendidikan akan mampu berjalan sesuai dengan kaidah internasional tanpa meninggalkan kebutuhan lokal. Penting melakukan penilaian kebutuhan sebelum menyusun suatu kurikulum dalam kebijakan nasional serta memperhatikan aspek-aspek yang mengiringinya. Dalam pelaksanaannya jalannya pendidikan sendiri harus ada monitoring yang terus menerus untuk kemudian dijadikan sebagai bahan evaluasi tingkat keberhasilan dalam mencapai tujuan pendidikan. Evaluasi ini tentu saja tidak hanya menilai secara parsial pada tingkat pencapaian siswa terhadap materi pembelajaran tetapi bagaimana pendidikan itu dapat menghasilkan output yang sesuai dengan amanat Undang-Undang dan tujuan pendidikan nasional yaitu sebagai pribadi yang cerdas serta bertakwa.

Ketiga, tujuan yang semula hendak dicapai setelah membandingkan pendidikan antarnegara - yakni menumbuhkan rasa saling pengertian (understanding), saling menghormati, meningkatkan perdamaian dunia, dan kerjasama antarnegara melalui pertukaran pelajar, mahasiswa, guru, dosen, para profesional, teknisi, dan lain-lain, tidak menghalangi kepentingan politik atau misi suatu negara terhadap negara lain. Disini politik asosiasi budaya berjalan secara perlahan. Ketika menjajah Indonesia, Belanda pun melaksanakan pendidikan bagi Bumi Putera walalupun kurikulumnya mengikuti kurikulum model Belanda. Begitupula dengan Inggris saat menduduki India. Artinya ketika kita mengadopsi pola pendidikan dari luar tidaklah kita harus menjadikan pendidikan layaknya negara mereka tetapi mengambil hal-hal positif yang dapat meningkatkan pendidikan negara kita secara positif dengan tidak lupa tetap memperhitungkan dengan tujuan pendidikan yang ingin kita capai. Hal ini tentu saja tidak semudah membalik telapak tangan karena pola pendidikan yang kita adopsi dari luar merupakan satu kesatuan sistem yang sesuai dengan kondisi yang ada di negara mereka tetapi bukan tidak mungkin kita tetap bisa melakukannya dengan penyesuaian terhadap apa yang dibutuhkan oleh negara kita sehingga perencanaan yang benar-benar matang dengan perhitungan yang cermat tentu diperlukan sebelum menjalankan suatu kebijakan pendidikan.

Keempat, yang diketahui tentang pendidikan suatu negara adalah mencerminkan kondisi saat itu. Besok atau lusa, apalggi berselang tahunan, kondisinya belum tentu samadengan kondisi ketika pengamatan yang pertama dilakukan. Kompleksitas budaya, hukum, ekonomi, ideologi ataupun pendidikan suatu negara itu sendiri berubah-rubah dan susah ditebak kapan akan berubah atau kemana perubahan akan mengarah? Terlebih bila perubahan itu menyangkut politik negara, umumnya berpengaruh langsung terhadap kebijakan suatu negara. Sebut saja Indonesia ketika merdeka dari suatu penjajahan, sistem kebijakan pendidikannyasegera berubah secara signifikan. Bisa dibayangkan Arab Saudi misalnya, bila struktur pemerintahan mamlakah atau kerajaannya berubah menjadi republik apa yang akan terjadi dengan pendidikannya? Kompleksitas tersebut bertambah rumit 
karena faktor nonpendidikan yang berpengaruh mengalami interaksi sinergik dalam perubahan pendidikan suatu negara. Pengaruh globalisasi juga tidak dapat dikesampingkan. Begitu euforia reformasi melanda Indonesia, negeri jiran (Malaysia) yang menyaksikannya lewat media informasi bisa jadi terinduksi.

Tujuan pendidikan diartikan sebagai suatu kondisi ideal yang akan dicapai peserta didik. Para peserta didik kelak akan menjalankan profesi-profesi di masyarakat bukan sekedar mendapatkan materi untuk kehidupannya di dunia, tetapi juga dilandasi motivasi menjalankan kewajibannya untuk memudahkan kehidupan masyarakat. Pendidikan era global tidak hanya melakukan proses untuk mencapai output yang berstandar internasional tetapi juga membawa identitas bangsa dalam outputnya dalam rangka memudahkan pembangunan dan peningkatan kualitas bangsa.

\section{KECERDASAN INTELEKTUAL DAN KECERDASAN SPIRITUAL DALAM DUNIA PENDIDIKAN ERA GLOBAL}

Kecerdasan atau inteligensi dalam bahasa Inggris disebut Intelligence. Sebagaimana dikutip oleh Crow dan Crow (1984: 205), bahwa intelegensi berarti kapasitas umum dari seorang individu yang dapat dilihat pada kesanggupan pikirannya dalam mengatasi tuntutan kebutuhan-kebutuhan baru, keadaan ruhaniah secara umum yang dapat menyesuaikan dan meghadapi problema-problema dan kondisi-kondisi yang baru dalam kehidupan. Secara inteligensi artinya orang yang cerdas adalah orang yang memiliki sikap dan tanggap dalam menyikapi suatu persoalan serta mampu menyesuaikan diri untuk menghadapinya.

Awalnya intelegensi hanya dikaitkan dengan sisi intelektual namun beberapa penelitian yang pernah dilakukan sampai akhirnya Daniel Goleman (1999: 411-421) mempopulerkan hasil penelitian Peter Salovey dan John Mayer tentang kecerdasan emosional. Goleman mengatakan bahwa hasil survey di Amerika serikat menunjukkan semakin tinggi skor IQ anak-anak, kecerdasan emosi mereka justru semakin menurun. Kemudian diawal tahun 2000 Danah Zohar dan Ian Marshal (2000: 4), masing-masing dari Harvard University dan Oxford University, membuktikan secara ilmiah adanya kecerdasan spiritual. Menurut mereka hal ini didasarkan pada temuan dua ahli yaitu pertama Michael Persinger dan Ramachandran (ahli psikologi saraf), menemukan eksistensi God spot dalam diri manusia yang terletak diantara jaringan syaraf dan otak manusia. Kedua Wolf singer menemukan adanya proses saraf dalam otak manusia yang terkonsentrasi pada usaha yang mempersatukan dan memberi makna dalam pengalaman hidup kita.

Istilah spiritual sendiri berasal dari kata spirit. Dalam Kamus Besar Bahasa Indonesia (2002: 1087) kata spirit diartikan: "semangat, jiwa, sukma, roh". Menurut Al-Ghazali (Badawi Thabanah, t.t :24) roh yang dimaksud memiliki dua makna yaitu: Pertama, berarti tubuh yang halus yang sumbernya adalah lubang hati yang jasmani, lalu tersebar melalui urat-urat yang mengalir ke dalam anggota tubuh, dan karenanya anggota-anggota tubuh itu dapat berfungsi. Kedua, berarti yang halus dari hati manusia yang mengerti dan mengetahui, ia adalah dimensi rohaniah manusia. 
Indikator spiritual ini sendiri menurut M. Zurkani Yahya (1996: 230) dapat dilihat dari kesadaran jiwa untuk memperbaiki diri, kemampuan menguasai diri, kesenangan yang meiliki dasar, ketakutan terhadap kesenangan, penolakan mengandalkan sesuatu selain dirinya, kecendrungan kepada Tuhan serta hanya menyandarkan segala sesuatu kepada Tuhan. Ciri-ciri ini menujukkan bahwa kecerdasan seseorang secara spiritual dapat dilihat secara langsung dalam perbuatannya. Bagaimana ia menyikapai persoalan dalam hidupnya dan menjalankan kesehariannya. Indikator spiritual ini akan mudah ditangkap melalui kepribadian seseorang yang dapat menjadikan dirinya sebagai pribadi yang menyenangkan dan terpercaya. Seorang peserta didik harus dikembangkan semua jenis kecerdasannya baik intelektual maupun spiritual karena semuanya dituntut dalam perjalanan hidupnya sebagai pemimpin di muka bumi. Kompetensi penguasaan ilmu yang cukup disertai sikap mental yang baik dan terkorelasi dengan keterikatan terhadap Tuhan membuat seseorang selalu mampu menyelesaikan segala macam masalah yang dihadapinya dalam kehidupan baik masalah pribadi, keluarga maupun masalah - masalah yang terjadi dalam kehidupan masyarakat dan negara.

Malik Fajar (1999: 118), sudah waktunya dicari usaha ke arah tercapainya suatu sintesis, konvergensi, atau sinergisitas, sehingga dapat dicapai kesatuan antara moralitas dan spiritualitas. Semua ini akan mampu mencetak generasi terbaik untuk masa depan dimana generasi ini diharapkan menjadi generasi terbaik dan unggul dimasa depan. Jika satu sama lain terpisah maka memungkinkan bangsa ini memiliki ketidakseimbangan yang mneyebabkan keberhasilan generasinya hanya pada satu sisi saja sedangkan sisi lainnya terpuruk. Indikator keberhasilan suatu negara tentu tidak hanya tercapainya kemajuan secara pembangunan tetapi juga tingkat berfikir dan bersikap warga negaranya. Kemajuan pendidikan yang baik akan menghasilkan output yang unggul disegala bidang.

Dalam kurikulum 2013 pun nampaknya hal ini mulai sudah diperhatikan. Kita lihat dalam penataan Kurikulum pada Kurikulum 2013 dilakukan sebagai amanah dari Undangundang nomor 20 tahun 2003 tentang Sistem Pendidikan Nasional dan Peraturan Presiden Nomor 5 Tahun 2010 tentang Rencana Pembangunan Jangka Menengah Nasional. Sinergitas dari ketiga efektifitas pembelajaran tersebut akan menghasilkan sebuah transfomasi nilai yang bersifat universal, nasional dengan tetap menghayati kearifan lokal yang berkembang dalam masyarakat Indonesia yang berkarakter mulia. Orientasi Kurikulum 2013 adalah terjadinya peningkatan dan keseimbangan antara kompetensi sikap (attitude), keterampilan (skill) dan pengetahuan (knowledge). Hal ini sejalan dengan amanat UU No. 20 Tahun 2003 sebagaimana tersurat dalam penjelasan Pasal 35: kompetensi lulusan merupakan kualifikasi kemampuan lulusan yang mencakup sikap, pengetahuan, dan keterampilan sesuai dengan standar nasional yang telah disepakati.

Empat faktor lainnya yang juga menjadi alasan Pengembangan Kurikulum 2013 adalah:

1. tantangan masa depan diantaranya meliputi arus globalisasi, masalah lingkungan hidup, kemajuan teknologi informasi, konvergensi ilmu dan teknologi, dan ekonomi berbasis pengetahuan. 
2. kompetensi masa depan yang antaranya meliputi kemampuan berkomunikasi, kemampuan berpikir jernih dan kritis, kemampuan mempertimbangkan segi moral suatu permasalahan, kemampuan menjadi warga negara yang efektif, dan kemampuan mencoba untuk mengerti dan toleran terhadap pandangan yang berbeda.

3. fenomena sosial yang mengemuka seperti perkelahian pelajar, narkoba, korupsi, plagiarisme, kecurangan dalam berbagai jenis ujian, dan gejolak sosial (social unrest).

4. Persepsi publik yang menilai pendidikan selama ini terlalu menitikberatkan pada aspek kognitif, beban siswa yang terlalu berat, dan kurang bermuatan karakter. (Pusat Kurikulum dan Perbukuan Kementerian Pendidikan dan Kebudayaan)

Menurut Ali Shariati sebagaimana dikutip oleh Ari Ginanjar Agustian (2001: 16-17) manusia adalah makhluk dua dimensi yang membutuhkan penyelarasan kebutuhan akan kepentingan dunia dan akhirat. Oleh sebab itu manusia harus memiliki konsep kepekaan emosi serta intelegensi yang baik dan penting pula penguasaan ruhiah vertikal atau spiritual quotient.

Dalam upaya untuk menyeimbangkan kecerdasan spiritual ada beberapa langkah yang harus dilakukan meliputi penjernihan emosi, pembangunan mental, ketangguhan pribadi, ketangguhan sosial, dan aplikasi total.

Penjernihan emosi: sebelum kita membahas tentang bagaimana menjernihkan emosi mari kita lihat QS. al Baqarah ayat 74:

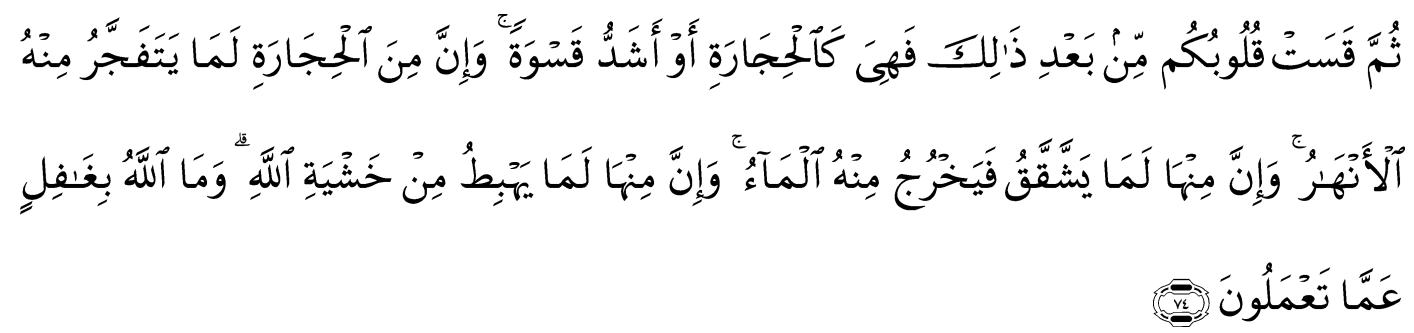

Artinya:

"Kemudian setelah itu hatimu menjadi keras seperti batu, babkan lebih keras lagi. padahal diantara batu-batu itu sungguh ada yang mengalir sungai-sungai dari padanya dan diantaranya sunggub ada yang terbelab lalu keluarlah mata air dari padanya dan diantaranya sunggub ada yang meluncur jatuh, Karena takut kepada Allah. dan Allah sekali-sekali tidak lengah dari apa yang kamu kerjakan."

Tindakan seseorang sangat bergantung dengan pemikirannya. Setiap orang akan merespon hal-hal yang dihadapinya sesuai dengan tingkatan berfikirnya. Dalam pendidikan haruslah kita mengupayakan berfikir yang baik dan menghilangkan prasangka negatif. Diasah dengan pengharapan tinggi kepada Tuhan, menjauhkan diri kita dari pengalaman yang membelenggu fikiran, meletakkan kepentingan dan prioritas dalam kerangka kebenaran,melihat semua sudut pandang secara bijaksana. Memacu anak-anak dengan pemikiran positif penting dilakukan dalam proses pembelajaran. Tentunyanya pemikiran positif ini akan sinergis dengan rangsangan yang diberikan kepada mereka dari penyikapan dan lingkungan yang terbentuk untuk memicu pola berfikir positif terhadap proses belajar mengajar itu. Proses pembelajaran bukanlah proses yang hanya meletakkan penyampaian 
materi pembelajaran tetapi ia merupakan proses pembentukan karakter peserta didik dimana mereka akan menjadi generasi penerus yang akan menempati posisi-posisi penting dan strategis bangsa Indonesia ke depannya. Pembiasaan sikap positif ini akan menghasilkan generasi yang tidak pantang menyerah dan selalu menyandarkan pengharapan yang tinggi kepada Tuhan.

Sikap yang demikian juga akan menghasilkan manusia-manusia yang gigih berusaha untuk menghasilkan segala yang terbaik yang mereka mampu dan hanya mengharapkan balasan terbaik dari Allah. Mental-mental ini sepertinya sangat sulit kita temui dewasa ini, dimana kita melihat banyaknya kasus korupsi baik di dunia politik maupun dunia pendidikan sendiri. Korupsi ini tentu saja disebabkan emosi yang tidak jernih dimana mereka hanya mengejar kesenangan sementara. Sebagaimana yang juga terjadi pada kasuskasus yang mengiringi kejahatan dikalangan remaja dan pelajar.

Penjernihan emosi akan menghasilkan hubungan keimananan yang memberikan kepemilikan rasa aman intrinsik yang menghasilkan kepercayaan diri yang sangat tinggi, integritas yang sangat kuat, sikap bijaksana dan memiliki tingkat motivasi yang sangat tinggi yang semuanya dilandasi dan dibangun karena iman dan prinsip hanya kepada Allah.di era globalisasi sifat seperti ini tentu saja diperlukan agar output pendidikan yang dihasilkan mampu terjuan dalam persaingan global tanpa menghilangkan sisi kualitas spiritual dalam dirinya.

Tentu saja semua ini akan berefek pada sifat output pendidikan yang memiliki loyalitas tinggi, komitmen yang kuat, memiliki kebiasaan untuk mengawali, memberi, suka menolong dan memiliki sikap saling percaya. Memiliki sikap kepemimpinan dimana seorang pemimpin adalah seseorang yang selalu mencintai dan memberi perhatian kepada orang lain, sehingga ia dicintai memiliki integritas yang kuat, dipercaya oleh pengikutnya. Memiliki kepribadian yang kuat serta konsisten. Dan yang terpenting adalah memimpin berlandaskan suara hati yang fitrah. Ia pada akhirnya akan memiliki akan memilki kebiasaan membaca situasi dengan cermat, berfikir kritis dan mendalam. Selalu mengevaluasi pemikiran serta bersikap terbuka untuk penyempurnaan. Selalu berorientasi pada tujuan akhir. Memiliki kesadaran, ketenangan dan keyakinan dalam berusaha.

Ketangguhan pribadi: ketangguhan pribadi adalah kondisi dimana seseorang telah memiliki pegangan atau prinsip hidup yang jelas. Prinsip ini akan membentuknya mennjadi pribadi yang tidak mudah terpengaruh oleh lingkungan yang terus berubah-rubah disekitarnya. membentuk ketanggguhan pribadi tentu tidaklah mudah namun dengan proses yang cermat dalam dunia pendidikan adalah meletakkan pendidikan untuk menghasilkan pribadi yang tangguh untuk mengimbangi kualitas kecerdasan intelektual yang diharapkan dari proses pendidikan itu sendiri. Langkah-langkah ini dapat dilakukan dengan membiasakan peserta didik membangun sebuah keyakinan dalam berusaha agar mereka tidak cepat menyerah dan berputus asa terhadap keadaan. Pada ujian sekolah atau ujian nasional misalnya patutlah kita membiasakan peserta didik agar percaya diri dengan hasil yang mereka dapatkan untuk melalui ujian tersebut setelah membantu mereka berusaha dengan semaksimal mungkin untuk meraih hasil yang terbaik. Generasi yang 
terbentuk dengan sikap ini akan tangguh dalam menghadapi berbagai persoalan dalam hidupnya, tidak akan mudah menyerah dan senantiasa menyandarkan segala sesuatu pada kemampuan yang dimilikinya dan bukan bersikap malas serta terima jadi dalam setiap tugas atau pekerjaan yang diamanhkan kepada mereka. Disisi lain diperlukan relaksasi pemikiran dalam rangka menjaga diri dalam meiliki cara berfikir yang jernih agar mereka terbiasa untuk menyikapai berbagai persoalan tanpa tergesa-gesa dalam mengambil keputusan. Tentu diperlukan metode untuk pengendalian diri. Dalam proses pendidikan hal ini bisa didapatkan dengan menanamkan kebiasaan membiasakan siswa dalam memecahkan persoalan. Dalam hal ini penting menanamkan sikap sabar dan teliti pada peserta didik agara mereka tidak terburu-buru dalam mengambil keputusan. Diharapkan output yang lahir dari sini adalah pribadi yang tidak mudah digoyahkan oleh kegagalan ataupun persepsi negatif dari luar.

Ketanggguhan sosial: Ketangguhan sosial adalah kemampuan dimana seseorang mampu bersikap empati, percaya, kooperatif serta terbuka terhadap lingkungan. Dalam proses pendidikan hal ini tentu saja sudah lama dilakukan misalnya dengan memberikan keloompok kerja dalam proses belajar mengajar. Bagaimana agar kelompok kerja ini dapat membuat peserta didik terbiasa dengan kerjasama dan sikap menerima dan tolong menolong satu sama lain. Diharapkan mereka tidak menjadi generasi yang individualistik dimasa depan dan selalu memiliki kepekaan sosial. Sebagaimana al-Qur'an mengajarkan manusia dalam al-Qashash: 84

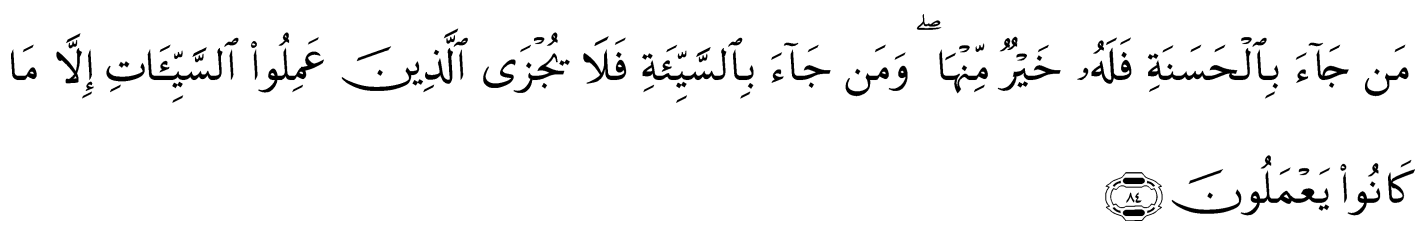

Artinya:

"Barangsiapa yang datang dengan (membawa) kebaikan, Maka baginya (pahala) yang lebih baik daripada kebaikannya itu; dan barangsiapa yang datang dengan (membawa) kejahatan, Maka tidaklah diberi pembalasan kepada orang-orangyang Telah mengerjakan kejahatan itu, melainkan (seimbang) dengan apa yang dabulu mereka kerjakan."

Aplikasi total: ialah dimana kita membiasakan proses pendidikan selalu mentransformasikan nilai-nilai spiritual secara total, konsisten dan dapat tervisualisasi dalam upaya mengenal jati dirinya.

\section{PENUTUP}

Globalisasi merupakan sesuatu yang tidak mungkin bisa kita bendung. Globalisasi tentu saja memiliki efek baik positif maupun negatif terhadap sauatu negara karena globalisasi memungkinkan adanya hubungan antar negara yang menyebabkan kemungkinan adanya pertukaran adat, budaya, norma bahkan pergeseran nilai agama. Hanya saja kita tidak bisa menolak serta merta adanya globalisasi karena globalisasi terkait 
dengan kemajuan terhadap bangsa kita. Yang terpenting adalah bagaimana kita dapat menjaring nilai-nilai negatif dari globalisasi.

Dunia pendidikan dalam hal ini memiliki peranan yang sangat besar dikarenakan melalui proses pendidikan inilah generasi bangsa disiapkan. Harpannya bukan hanya pendidikan menghasilkan generasi unggul dalam hal intelektual tetapi juga unggul secara spiritual yang akan berfungsi dalam rangka menjaga generasi bangsa dari efek negatif globalisasi.

Pendidikan spiritual bukanlah sesuatu yang harus dipisahkan dari pendidikan formal karena pada dasarnya ia dapat diaplikasikan melalui pendidikan formal dengan cara penerapan nilai-nilai spiritual itu ke dalam proses pendidikan formal. Sehingga nilai spiritual itu tidak hanya dihadirkan dalam mata pelajaran agama tetapi juga dalam setiap proses pendidikan.

\section{DAFTAR PUSTAKA}

Assegaf, Rahman. 2003. Internasionalisasi Pendidikan. Yogyakarta: Gama Media

Azizy, Qodry. 2004. Melawan Globalisasi: Reinterpretasi Ajaran Islam Persiapan SDM dan Terciptanya Masyarakat Madani. Yogyakarta: Pustaka Pelajar.

Basuki, H.A Hafidz. 1982. Pembinaan Pendidikan Agama. Jakarta: Depag R.I

D. Crow, Lester dan Alice Crow. 1984. Educational Psycology. Diterjemahkan Z. Kasjian dengan judul Psikologi Pendidikan. Surabaya: Bina Ilmu

Darmaningtyas. 1999. Pendidikan Pada dan Setelah Krisis (Evaluasi Pendidikan Pada Masa Krisis). Yogyakarta: Pustaka Pelajar

Departemen Pendidikan Nasional. 2002. Kamus Besar Bahasa Indonesia. Jakarta: Balai Pustaka Fajar, Malik. 1999. Reorientasi Pendidikan Islam. Jakarta: Fajar Dunia

Fatah, Nanang. 2012. Analisis Kebijakan Pendidikan. Bandung: Remaja Rosdakarya

Goleman, Daniel. 1999. Working with Emotional Intelligence. New York: Bantam Books

http://edukasi.kompasiana.com/2012/11/19/mengatasi-kriminalitas-pelajar510254.html (diakses tanggal 10 Nopember 2013)

http://m.okezone.com/read/2013/02/01/373/755030/waspada-pergaulan-bebasremaja-ancaman-serius (diakses tanggal 10 Nopember 2013)

http: / / regional.kompas.com/read/2013/03/0 7/03184385/ Pengguna.Narkoba.di.Kalangan.Remaja.Meningkat (diakses tanggal 10 Nopember 2013)

Komara, Endang. 2005. Peran Pendidikan Islam dalam Era Globalisasi. http:// w w w. g e o c i t i e s. w s/e n d a n g. k o ma r a / PERAN_PENDIDIKAN_ISLAM_DALAM_ERA_GLOBALISASI.htm. (diakses tanggal 10 Nopember 2013) 
Nurcholish Madjid. 2004. Indonesia Kita. Jakarta: Gramedia.

Sumber : Pusat Kurikulum dan Perbukuan Kementerian Pendidikan dan Kebudayaan

Sztompka, Piötr. 2004. Sosiologi Perubahan Sosial. Terj. Alimandan dari "The Sociology of Social Change”. Jakarta: Prenada.

Thabanah, Badawi. t.t. Ibya 'Ulum al-Din Li al-Imam. Semarang: Usaha Keluarga

Zohar, Danah dan Ian Marshal. 2000. SQ: Spiritual Quetiont, the Ultimate Intelligence. London: Vloombury Publishing 